\section{Yield and Fruit Quality Traits of Two Banana Cultivars Grown at Two Locations in Puerto Rico under Black Leaf Streak Disease Pressure}

\author{
Ricardo Goenaga ${ }^{1}$, Brian Irish $^{1}$, and Angel Marrero ${ }^{1}$
}

ADDITIONAL INDEX WORDs. bunch yield, fruit number, Musa AAA, productivity, soluble sugars, starch

\begin{abstract}
SumMARY. Banana (Musa acuminata AAA) is the most exported fruit worldwide and represents a major source of revenue for Central American and South American countries as well as the Caribbean region, among others. Black leaf streak disease (BLSD) or black sigatoka, caused by Pseudocercospora fijiensis (formerly Mycosphaevella fijiensis), is responsible for significant losses to this crop due to the high susceptibility of the most economically important cultivars. BLSD does not immediately kill banana plants, but it causes severe leaf necrosis that results in reduced photosynthetic area, thereby adversely impacting bunch weight and fruit production. Without cultural and chemical control, yields can be reduced by $20 \%$ to $80 \%$, depending on severity. This study evaluated 'FHIA-17', a BLSD-resistant synthetic hybrid (AAAA), against 'Grand Nain', a standard commercial cultivar with no BLSD tolerance, at two locations in Puerto Rico on Ultisol (Corozal site) and Oxisol (Isabela site) soils where BLSD was not managed. Significantly lower bunch yield $\left(45,990 \mathrm{~kg} \cdot \mathrm{ha}^{-1}\right)$ and significantly fewer fruit $(220,671$ fruit/ha) were obtained at Corozal than at Isabela $\left(53,755 \mathrm{~kg} \cdot \mathrm{ha}^{-1} ; 380,241\right.$ fruit/ha). Lower production at Corozal was the result of higher severity of BLSD at this location than at Isabela and to soil factors interfering with optimum nutrient uptake. Average fruit production of 'FHIA-17' was significantly higher than that of 'Grand Nain' at both locations, with bunch yields of 68,105 and $72,634 \mathrm{~kg} \cdot \mathrm{ha}^{-1}$ at Corozal and Isabela, respectively. Fruit of the thirdupper hand was significantly longer for 'FHIA-17' at Corozal but not different at Isabela; however, 'FHIA-17' fruit in this hand were of significantly greater diameter. Fruit in the last hand of 'FHIA-17' were significantly longer than in 'Grand Nain' at Corozal, but of significantly greater diameter at both locations. At both locations, the mean fruit weight was significantly higher in 'FHIA-17' than in 'Grand Nain'. The number of functional leaves present at flowering and at harvest was significantly higher in 'FHIA-17' than in 'Grand Nain' at both locations, indicating more availability of photosynthetic area in 'FHIA-17' during the fruit-filling period. The harvest cycle of 'FHIA-17' was significantly longer than for 'Grand Nain'. It took 315 and 204 more days in Corozal and Isabela, respectively, to harvest three cycles (mother crop and two ratoon crops) of 'FHIA-17' than for 'Grand Nain'. No significant differences were found for starch and soluble sugars in green unripe or fully mature fruit among cultivars. In this long-term study, 'FHIA-17' showed to have good production and resistance against BLSD and is a viable alternative to current commercial cultivars. Its relative advantage of reduced production costs by not needing fungicide applications should be weighed against its longer harvest cycle to produce a fruit bunch.
\end{abstract}

$\mathrm{B}$ anana is a tropical rhizomatous perennial plant whose center of origin lies in the humid tropical belt that extends from India to the Solomon Islands (Bioversity International, 2020a; Perrier et al., 2011). India is the largest banana-producing country followed by China, Indonesia, Ecuador, and the Philippines, accounting for 53\% of total world production [Food and Agriculture Organization of the United Nations (FAO), 2020]. Ecuador is the largest banana exporter, totaling $27 \%$ of world exports (FAO, 2020); however, banana production also represents a major source of revenue in Central America and the Caribbean region
(Bioversity International, 2020b). In the United States, smaller scale commercial production occurs in Puerto
Rico (5051 acres), Hawaii (1159 acres), and southern Florida (952 acres), where producers supply local and regional markets [Bioversity International, 2020b; Crane and Balerdi, 2019; U.S. Department of Agriculture (USDA), 2017]. Bananas are commercially packed as individual fruit (i.e., "fingers"), clusters, hands, or in a combination of clusters and hands. A cluster is at least two but not more than seven fingers attached to the crown (cut portion of stalk). A hand is eight or more fingers attached to the crown (USDA, 2004).

Banana classification is based on the nomenclature developed by Simmonds and Shepherd (1955). Most edible bananas originally came from two wild, seeded species, M. acuminata (A genome) and Musa balbisiana (B genome). The genomic contributions from these two species determines the ploidy and genetic makeup or subgroups. For example, the "AAA" genomic group forms the most commercially valuable group and is composed of several subgroups of which the "Cavendish" subgroup is the most important for export and local markets. Important cultivars in this subgroup include Grand Nain, Williams, and Mons Mari, among others (Bioversity International, 2020c; Robinson and Galán-Saúco, 2010; Subbaraya et al., 2011). Other genomic groups include "AAAA" (tetraploid banana), produced by breeding "AA" pollen parents with "AAA" female parents, "AAB" (plantains), "ABB" (cooking banana), "AAB" (dessert bananas), and even manmade or synthetic tetraploid hybrids (AABB) (Bioversity International, 2020c; Irizarry et al., 2001).

Since its description in 1963 (Rhodes, 1964), BLSD has spread to most banana and plantain growing regions. The first record of BLSD in Latin America is from Honduras in 1972 and since then the disease has spread to Belize (1975); Guatemala

\begin{tabular}{llll}
\hline $\begin{array}{l}\text { Units } \\
\begin{array}{l}\text { To convert U.S. to SI, } \\
\text { multiply by }\end{array}\end{array}$ & U.S. unit & SI unit & $\begin{array}{l}\text { To convert SI to U.S., } \\
\text { multiply by }\end{array}$ \\
\hline 0.4047 & $\mathrm{acre}(\mathrm{s})$ & $\mathrm{ha}$ & 2.4711 \\
100 & $\mathrm{bar}$ & $\mathrm{kPa}$ & 0.01 \\
0.3048 & $\mathrm{ft}$ & $\mathrm{m}$ & 3.2808 \\
2.54 & inch $(\mathrm{es})$ & $\mathrm{cm}$ & 0.3937 \\
25.4 & inch $(\mathrm{es})$ & $\mathrm{mm}$ & 0.0394 \\
0.4536 & lb & $\mathrm{kg}$ & 2.2046 \\
1.1209 & $\mathrm{lb} / \mathrm{acre}$ & $\mathrm{kg} \cdot \mathrm{ha}^{-1}$ & 0.8922 \\
28.3495 & $\mathrm{Oz}$ & $\mathrm{g}$ & 0.0353 \\
0.001 & $\mathrm{ppm}$ & $\mathrm{mg} \cdot \mathrm{g}^{-1}$ & 1000 \\
1 & $\mathrm{ppm}$ & $\mathrm{mg} \cdot \mathrm{kg}^{-1}$ & 1 \\
$\left({ }^{\circ} \mathrm{F}-32\right) \div 1.8$ & ${ }^{\circ} \mathrm{F}$ & ${ }^{\circ} \mathrm{C}$ & $\left({ }^{\circ} \mathrm{C} \times 1.8\right)+32$ \\
& & &
\end{tabular}


(1977); Nicaragua, El Salvador, and Costa Rica (1979); Mexico (1980); Panama and Colombia (1981); Ecuador (1986); Venezuela (1991); Peru (1994); Bolivia (1996); Brazil (1998); Bahamas (2004); and French Guiana (2008). In the Caribbean region, the disease was first reported in Cuba (1992), Jamaica (1994), Dominican Republic (1996), Haiti (2000), Trinidad and Tobago (2003), Grenada (2005), Saint Vincent (2009), Saint Lucia and Martinique (2010), and Dominica and Guadeloupe (2012) (Robinson and Galán-Saúco, 2010). In the continental United States, BLSD was first found in Florida in 1998 (Ploetz and Mourichon, 1999) and confirmed in the U.S. territory of Puerto Rico in 2004 (Irish et al., 2006).

Although banana production in the Western Hemisphere is seriously threatened by the emergence of a strain of the soilborne fungus Fusarium oxysporum $\mathrm{f}$. sp cubense tropical race 4 [Foc TR4 (Maymon et al., 2020; Yonow et al., 2019)], BLSD continues to be one of the most limiting factors in banana production worldwide. BLSD does not immediately kill its host plants but causes severe leaf necrosis that results in reduced photosynthetic area affecting bunch weight and fruit quality. Without chemical and cultural control, yields can be reduced by $20 \%$ to $80 \%$, depending on disease severity (Churchill, 2011; Etebu and Young-Harry, 2011). Fruit harvested from heavily infected plants ripen prematurely and unevenly and result in unmarketable fruit. The need to manage the disease to a level that does not affect fruit

Received for publication 12 July 2021. Accepted for publication 30 Aug. 2021.

Published online 18 October 2021.

${ }^{1}$ U.S. Department of Agriculture, Agricultural Research Service, Tropical Agriculture Research Station, 2200 P.A. Campos Avenue, Suite 201, Mayaguez, PR 00680-5470

We thank Jose Luis Rodriguez, for excellent assistance in management of experiment and data collection at Corozal, and Delvis Pérez for chemical analyses.

Mention of trade names or commercial products in the paper is solely for the purpose of providing specific information and does not imply recommendation or endorsement of the U.S. Department of Agriculture.

R.G. is the corresponding author. E-mail: ricardo. goenaga@usda.gov.

This is an open access article distributed under the CC BY-NC-ND license (https://creativecommons. org/licenses/by-nc-nd/4.0/).

https://doi.org/10.21273/HORTTECH04914-21 production and quality makes BLSD the most economically important foliar disease of banana. In Puerto Rico, BLSD has steadily led to higher production costs associated with added labor for cultural practices and increased use of fungicides (Alamo et al., 2007). Approximately $30 \%$ of the total cost of production is associated with pruning of heavily infected, nonfunctional leaves and the use of chemical control measures for BLSD (Etebu and Young-Harry, 2011).

Managing BLSD with fungicidal applications can be expensive and can be hazardous to human health and the environment; therefore, breeding for disease resistance offers the most sustainable and effective means of disease management. Several international breeding programs have released BLSDtolerant plantain and banana hybrids, most of which are parthenocarpic synthetic tetraploids generated by crossing triploid banana and fertile, true plantain cultivars with wild or improved diploid (Musa AA) parents (Ortiz et al., 1998; Robinson and Galán-Saúco, 2010; Rowe and Rosales, 1993; Swennen and Vuylsteke, 1993).

The USDA, Agricultural Research Service (ARS), Tropical Agriculture Research Station (TARS) in Mayaguez, $\mathrm{PR}$, is the official repository for Musa species germplasm for the National Plant Germplasm System. The authors have introduced to the repository disease-resistant banana genotypes for field evaluation from international breeding programs (Irish et al., 2013). In this study, the authors compared performance by measuring yield and fruit quality traits in two banana cultivars grown under BLSD pressure at two locations in Puerto Rico.

Table 1. Average preplant soil characteristics at two banana test sites in Puerto Rico (Corozal and Isabela) measured to a depth of $25 \mathrm{~cm}$ (9.8 inches).

\begin{tabular}{|c|c|c|}
\hline Soil characteristics ${ }^{\mathrm{z}}$ & Corozal (Ultisol) & Isabela (Oxisol) \\
\hline $\mathrm{pH}$ in water & 4.87 & 6.36 \\
\hline $\mathrm{pH}$ in calcium chloride & 4.21 & 5.77 \\
\hline Ammonium nitrogen $\left(\mathrm{mg} \cdot \mathrm{kg}^{-1}\right)$ & 155 & 41 \\
\hline Nitrate nitrogen $\left(\mathrm{mg} \cdot \mathrm{kg}^{-1}\right)$ & 14 & 22 \\
\hline Organic carbon $(\%)$ & 1.57 & 1.52 \\
\hline Phosphorous $\left(\mathrm{mg} \cdot \mathrm{kg}^{-1}\right)$ & 8 & 30 \\
\hline Potassium $\left(\mathrm{mg} \cdot \mathrm{kg}^{-1}\right)$ & 125 & 143 \\
\hline Calcium $\left(\mathrm{mg} \cdot \mathrm{kg}^{-1}\right)$ & 1352 & 1625 \\
\hline Magnesium $\left(\mathrm{mg} \cdot \mathrm{kg}^{-1}\right)$ & 102 & 95 \\
\hline Aluminum $\left(\mathrm{mg} \cdot \mathrm{kg}^{-1}\right)$ & 238 & $\mathrm{ND}^{\mathrm{y}}$ \\
\hline
\end{tabular}

${ }^{\mathrm{z}} 1 \mathrm{mg} \cdot \mathrm{kg}^{-1}=1 \mathrm{ppm}$.

${ }^{y}$ Not detectable.

\section{Materials and methods}

This study was conducted in 2010-13 in Puerto Rico at the USDAARS-TARS Research Farm in Isabela (Coto clay: clayey, kaolinitic isohyperthermic Typic Hapludox) and at the Corozal Agricultural Experiment Station of the University of Puerto Rico (Corozal clay: clayey, mixed, isohyperthermic Aquic Haplohumults). Soil and climatic characteristics are described in Tables 1 and 2 , respectively. Soil samples from each site were collected 2 months before planting by taking 15 borings at a depth of 0 to $25 \mathrm{~cm}$ from each of the projected cultivar rows. Samples were air-dried and passed through a 16-mesh screen. Soil $\mathrm{pH}$ in water and $0.01 \mathrm{M}$ calcium chloride ( 1 soil: 2 water) were measured with a glass electrode. Phosphorous (P) and exchangeable cations [potassium (K), magnesium $(\mathrm{Mg})$, and calcium $(\mathrm{Ca})]$ were extracted with Mehlich III solution [extract was composed of $0.2 \mathrm{M}$ acetic acid, $0.25 \mathrm{M}$ ammonium nitrate, $0.015 \mathrm{M}$ ammonium fluoride, 0.013 $M$ nitric acid, and $0.001 \mathrm{M}$ EDTA (Amacher, 2007)], Exchangeable aluminum (Al) was extracted with $1 \mathrm{~N}$ potassium chloride. All elements were determined by inductively coupled plasma spectrometry (Sumner and Miller, 2007). Organic carbon was determined by the Walkley-Black method (Nelson and Sommers, 2007). Soil ammonium $\left(\mathrm{NH}_{4}\right)$ and nitrate $\left(\mathrm{NO}_{3}\right)$ were determined by steam distillation (Mulvaney, 2007).

The banana cultivars evaluated in the experiment were the BLSD-tolerant FHIA-17 (Musa AAAA) and the disease-susceptible Grand Nain (Musa AAA) "Cavendish" subgroup. 'FHIA17' was developed at the Fundación 
Table 2. Weather data at two banana test sites in Puerto Rico (Corozal and Isabela) in 2010-13.

\begin{tabular}{lcc}
\hline Site characteristics & Corozal & Isabela \\
\hline Total rainfall $(\mathrm{cm})$ & 159 & 164 \\
Maximum temperature $\left({ }^{\circ} \mathrm{C}\right)$ & 29.6 & 28.4 \\
Minimum temperature $\left({ }^{\circ} \mathrm{C}\right)$ & 20.4 & 21.4 \\
Elevation $(\mathrm{m})$ & 195 & 126 \\
\hline
\end{tabular}

${ }^{\mathrm{z}} 1 \mathrm{~cm}=0.3937$ inch, $\left(1.8 \times{ }^{\circ} \mathrm{C}\right)+32={ }^{\circ} \mathrm{F}, 1 \mathrm{~m}=3.2808 \mathrm{ft}$.

Hondureña de Investigación Agrícola (FHIA), Honduras, Central America (Fundación Hondureña de Investigaciones Agrícolas, 2021). 'Grand Nain' is the most extensively grown cultivar under commercial production worldwide. The 'FHIA-17' source planting material was obtained as virus-free (indexed), in vitro cultured plantlets from the Bioversity International's Musa International Transit Center at the Catholic University in Leuven, Belgium. Before field transplanting, 'FHIA-17' plant material was increased via in vitro micropropagation following conventional protocols (Vuylsteke, 1989) and acclimatized in a greenhouse for 3 months. Plants were regularly watered and fertilized with $20 \mathrm{~N}-8.7 \mathrm{P}-16.6 \mathrm{~K}+$ micronutrients water soluble fertilizer (Evergreen; Plant Foods, Vero Beach, $\mathrm{FL}$ ) and $19 \mathrm{~N}-2.6 \mathrm{P}-10 \mathrm{~K}$ slow-release fertilizer (Osmocote; The Scotts Co., Marysville, $\mathrm{OH}$ ). Six-month-old tissue cultured plantlets of 'FHIA-17' and medium-size corms obtained from sword suckers of 'Grand Nain' were planted at $6 \times 6$-ft spacing in a randomized complete block design with six replications. Within a replication, there were two plots of two rows to accommodate each treatment (cultivars). Each treatment plot had 14 plants of which the inner 10 were harvested. Alleys of $12 \mathrm{ft}$ separated the replications (equivalent to 806 plants/acre). Two guard plants of each cultivar separated the 10 experimental treatment plants between treatment plots and there were two guard rows at the end of each plot. The experiment was surrounded by three rows of BLSD-susceptible 'Grand Nain' banana plants that served as a source of natural inoculum for P. fijiensis.

Fertilization was provided using a $10 \mathrm{~N}-2.2 \mathrm{P}-24.9 \mathrm{~K}-1.8 \mathrm{Mg}$ granular commercial mixture by applying 0.25 and $0.5 \mathrm{lb}$ at 1 and 2 months after transplanting, respectively, and $1 \mathrm{lb}$ of fertilizer per plant thereafter every 3 months until the experiment was completed.
Nematodes, soilborne insects, and weeds were controlled by following recommended cultural practices (University of Puerto Rico, Agricultural Experiment Station, 1995). Plots were drip-irrigated when the soil water tension, measured with tensiometers (Irrometer Co., Riverside, CA) at a depth of $1 \mathrm{ft}$, exceeded 20 $\mathrm{kPa}$. No leaf pruning, or foliar spraying was carried out to control BLSD. A selective desuckering program was implemented $\approx 4$ months after planting to allow the development of a single ratoon sucker per stump for the subsequent crop.

At flowering (bunch-shooting) and harvest, the number of functional leaves per plant was recorded. Approximately 2 weeks after flowering, the male flower bud and the false hands were removed from the immature bunches. For the mother crop, the number of days to flower was determined as the time interval between field planting and flowering. For the ratoon crops, this was determined by counting the number of days elapsed between the mother crop harvest date and flowering. At flowering, plant height and pseudostem diameter were measured from mother and ratoon plants. These measurements were taken from the base of the plants to the point of bunch emergence for plant height and to $1 \mathrm{~m}$ aboveground level for pseudostem diameter.

Bunches were harvested when fruit reached the mature green stage, $\approx 110 \mathrm{~d}$ after flowering. At harvest, bunches were weighed, and the number of hands and fruit counted and then cut from the rachis. The length of the fruit on its outside edge and diameter at widest point were measured from three fruit of the middle section of the third-upper and last hands in the bunch. These fruit measurements were pooled to obtain an average for each hand. The weight for both third and last hands was also recorded. Values for bunch weight and yield per unit area were obtained after subtracting the rachis weight from the total bunch weight.

BLSD severity was assessed at flowering time for the mother and ratoon crops. Using Gauhl's modification of Stover's severity scale adapted from Orjeda (1998), all leaves for every plant evaluated were scored on a 0 to 6 scale where $0=$ no symptoms; $1=1 \%, 2=2 \%$ to $5 \%, 3=6 \%$ to $15 \%$, $4=16 \%$ to $33 \%, 5=34 \%$ to $50 \%$, and $6=>51 \%$ of the leaf area affected.

To determine the presence of $P$. fijiensis causing infection on evaluated banana cultivars from other possible related fungal species, 20 isolates were recovered for testing. Pure cultures (i.e., single ascospores) were isolated from randomly selected senescent leaf tissue from five 'Grand Nain' and five 'FHIA-17' plants from both the Corozal and Isabela locations using an ascospore discharge technique (Johanson and Jeger, 1993). Fungal mycelium was grown in potato dextrose broth on an orbital shaker, and harvested, lyophilized, and ground in a mortar and pestle in liquid nitrogen before DNA extraction. DNA was extracted using a DNeasy Plant Mini Kit (Qiagen, Valencia, CA) following the manufacturer's protocols for lyophilized fungal mycelium. DNA for each isolate was amplified using a $P$. fijiensis species-specific primer set (ACTR/MfactF) in combination with a positive internal control primer set (TMG3/TMG4) for the $\beta$-tubulin gene developed by Arzanlou et al. (2007). Polymerase chain reactions (PCRs) also included genomic DNA from pure cultures of $P$. fijiensis, and Psendocercospora musicola (yellow sigatoka), and Pseudocercospora eumusae (eumusae leaf spot) (provided by G. Kema, Wageningen University) as well as a negative water control to serve as references. All PCR reactions were performed as described by Arzanlou et al. (2007) on a thermocycler (T-100; Bio-Rad, Hercules, CA) and were electrophoresed in $1.5 \%$ agarose gels and stained with ethidium bromide. Agarose gels were visualized and photographed using a transilluminator (Epi Chemi II Darkroom; UVP, Upland, CA).

Analysis of variance was carried using the GLM procedure of SAS (version 9.4 for Windows; SAS Institute, Cary, NC). After a significant $\mathrm{F}$ test at $P \leq 0.05$, mean separation was 
Table 3. Yield and bunch traits of 'FHIA-17' and 'Grand Nain' banana planted at two locations in Puerto Rico under black leaf streak disease pressure. Values are means of six replications and 3 years (2010-13).

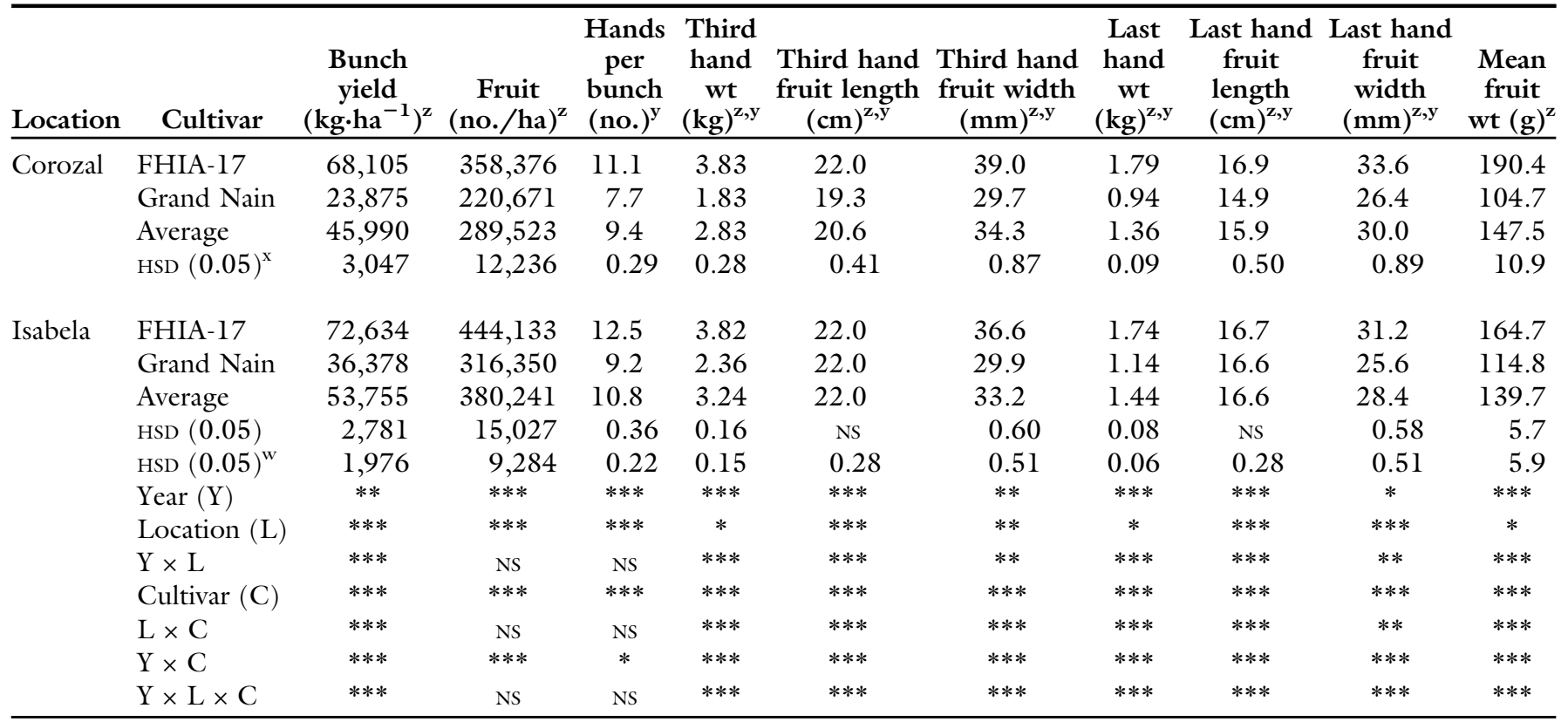

${ }^{\mathrm{z}} \mathrm{l} \mathrm{kg} \cdot \mathrm{ha}^{-1}=0.8922 \mathrm{lb} /$ acre, $\mathrm{l}$ fruit $/ \mathrm{ha}=0.4047$ fruit/acre, $\mathrm{l} \mathrm{kg}=2.2046 \mathrm{lb}, \mathrm{l} \mathrm{cm}=0.3937 \mathrm{inch}, \mathrm{l} \mathrm{mm}=0.0394 \mathrm{inch}, \mathrm{l} \mathrm{g}=0.0353 \mathrm{oz}$.

${ }^{\mathrm{y}}$ The first three upper hands of plantain bunches contain $\approx 50 \%$ of the total fruit. Therefore, the weight of the third-upper hand is often used to represent an average weight of all the hands in the bunch. Similarly, higher fruit weight and size in the last hand is indicative of higher marketable weight in fruit of hands after the third hand (Goenaga and Irizarry, 2006).

xukey's honestly significant difference test at $P=0.05$.

${ }^{\mathrm{w}}$ Compares means among locations.

Ns, *,**,***Nonsignificant or significant at $P \leq 0.05,0.01$, or 0.001 , respectively

performed with the Tukey's honestly significant difference range test. For comparison of BLSD resistance and yield performance and to prevent analyzing an incomplete data set, only three harvest cycles (mother crop and two ratoon crops) were statistically analyzed.

\section{Results and discussion}

Following PCR amplification, $P$. fijiensis infection was confirmed at both locations by electrophoretic separation and visualization of both the diagnostic $[\approx 500$ base pairs $(\mathrm{bp})]$ and $\beta$-tubulin gene $(\approx 300 \mathrm{bp})$ fragments from isolates recovered from both cultivars as well as in the positive control reference sample. All 10 isolates recovered from both cultivars from Isabela amplified the diagnostic $\approx 500$ bp and internal control fragments. In contrast, only two isolates/DNA samples from 'FHIA-17' and one from 'Grand Nain' amplified the $\approx 500$ bp and internal control fragment from Corozal. The remaining seven samples from Corozal amplified the internal $\beta$-tubulin gene fragment, but nothing else. In addition, only the internal $\beta$-tubulin gene fragment was amplified for both $P$. musicola, and $P$. eumusae reference samples and no amplification was seen for negative water control. These findings evidence the presence of BLSD in both locations.

Year, location, and cultivars showed highly significant effects $(P \leq$ 0.01 ) for most parameters measured in the study (Tables 3 and 4). Except for plant height, pseudostem diameter, bunch rachis weight, total number of fruit, and number of hands per bunch, the location $\times$ cultivar interaction was significant, indicating that cultivars responded differently for yield, fruit traits, plant attributes, and reaction to BLSD at both locations. The year $\times$ cultivar interaction was significant for all parameters studied except for plant height, indicating that plant height of cultivars was a stable trait across years (Tables 3 and 4 ).

Cultivars exhibited drastic yield differences between the mother (year 1 ) and ratoon (years 2, 3) crops (Tables 3 and 5). Contrary to the rapid yield decline that occurs in commercial plantain production after harvest of the mother crop (Goenaga et al., 1993, 2019), banana yields tend to increase in successive ratoon crops after harvest of the mother crop (Goenaga and Irizarry, 1995; Irizarry et al., 1989). In this study, the bunch yield obtained by the 'FHIA-17' second ratoon crop was $37 \%$ and $8 \%$ higher in Corozal and Isabela, respectively, than the mother crop. In 'Grand Nain', bunch yield for the second ratoon was $168 \%$ and $60 \%$ higher, respectively, than the mother crop (Table 5).

Average bunch yield, total number of fruit, as well as many other bunch and hand traits were significantly different between locations (Table 3). Significantly lower bunch yield $\left(45,990 \mathrm{~kg} \cdot \mathrm{ha}^{-1}\right)$ and significantly fewer fruit $(289,523$ fruit/ha) were obtained at Corozal than at Isabela $\left(53,755 \mathrm{~kg} \cdot \mathrm{ha}^{-1} ; 380,241\right.$ fruit/ ha). Lower bunch yield at Corozal than at Isabela was the result of significantly lower number of fruit harvested particularly in 'Grand Nain', which produced $30 \%$ fewer fruit at Corozal than at Isabela (Table 3). Less fruit production at Corozal could have been the result of several factors. Severity of BLSD was higher at Corozal than at Isabela, particularly in leaves 4 to 7 , which are photosynthetically active 
Table 4. Plant traits of 'FHIA-17' and 'Grand Nain' banana planted at two locations in Puerto Rico under black leaf streak disease pressure. Values are means of six replications and 3 years (2010-13).

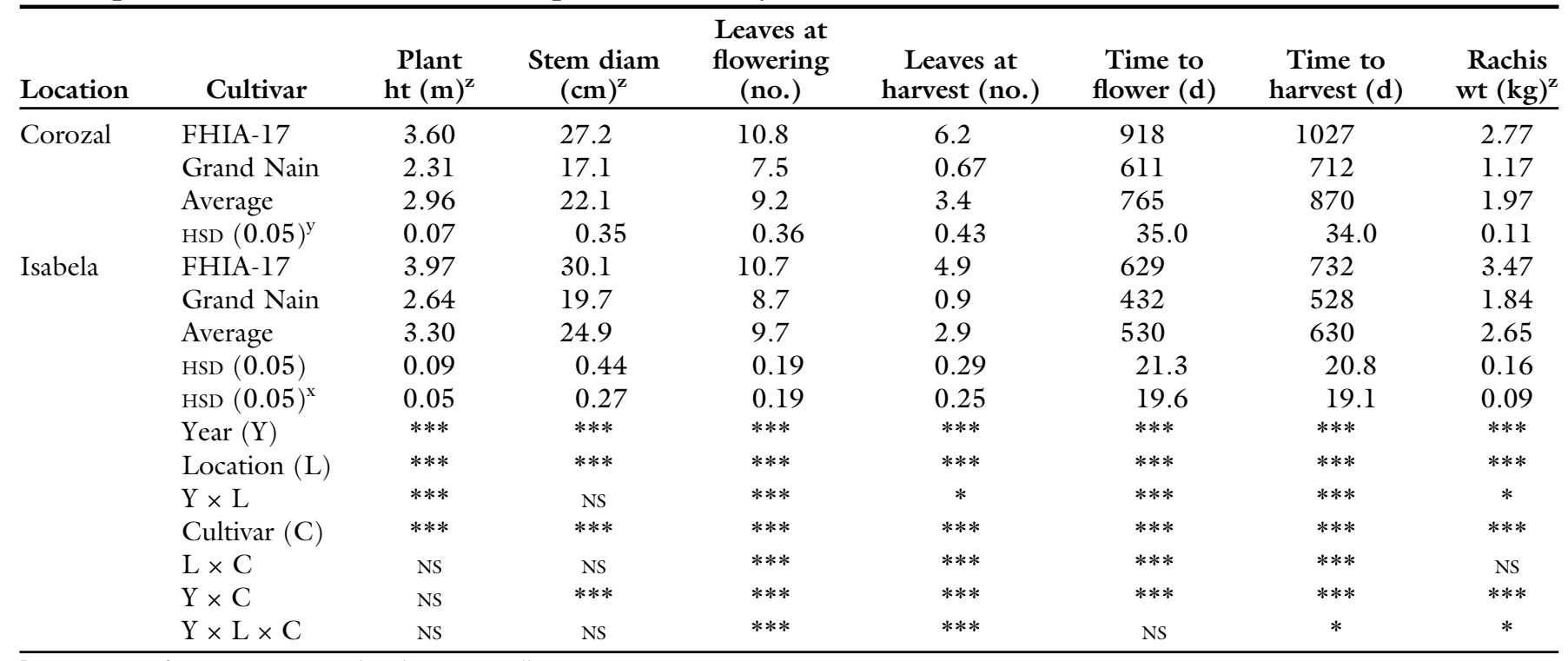

\footnotetext{
${ }^{\mathrm{z}} \mathrm{l} \mathrm{m}=3.2808 \mathrm{ft}, \mathrm{l} \mathrm{cm}=0.3937$ inch, $1 \mathrm{~kg}=2.2046 \mathrm{lb}$.

${ }^{\mathrm{y}}$ Tukey's honestly significant difference test at $P=0.05$.

${ }^{\mathrm{x}}$ Compares means among locations.

Ns, *,***Nonsignificant or significant at $P \leq 0.05$ or 0.001 , respectively.
}

(Robinson et al., 1992), particularly in plants having up to 12 leaves like in this study (Table 6). Another reason for lower productivity at Corozal may be related to soil factors interfering with optimum nutrient uptake. The soil at Corozal is a highly weathered Ultisol, typical of the humid tropics and are characterized by intensive leaching, moderate cation exchange capacity, high soil acidity, and, consequently, a low supply of bases (USDA, 1999). The soil at the Corozal site is more acidic and has a much higher concentration of $\mathrm{Al}$, than at Isabela (Table 1). High soil Al in the soil solution not only replaces divalent cations such as $\mathrm{Mg}$ and $\mathrm{Ca}$ but also inhibits root growth (Eckhard et al., 2012). Leaf tissue sampling conducted during the experimental period showed an average leaf $\mathrm{Mg}$ concentration of $0.22 \%(\mathrm{n}=65)$ for cultivars grown at Corozal (data not shown), whereas at Isabela was $0.31 \%(\mathrm{n}=44)$. Studies conducted by Irizarry et al. (1988, $1990,2000)$ showed that Mg concentration of $0.30 \%$ in leaves of banana and plantain grown in Ultisol soils is considered optimum for growth and productivity. These limiting growth factors may also help to explain shorter plants with smaller stem diameters, smaller rachis weights, and more days required to flower in plants at the Corozal site (Table 4).

At both locations, 'FHIA-17' produced significantly more fruit and yield per area than 'Grand Nain' (Tables 3 and 5 ). The weights of the third-upper and last hand in the bunch were also significantly higher in cultivar FHIA-17 than in Grand Nain (Table 3). Fruit of the third-upper bunch hand of 'FHIA17' were significantly longer at Corozal but not different at Isabela. However, 'FHIA-17' fruit in this hand were of significantly greater diameter at both locations (Table 3 ). Fruit in the bunch last hand of 'FHIA-17' were significantly longer at Corozal, but of

Table 5. Bunch and fruit yield of 'FHIA-17' and 'Grand Nain' banana grown at two locations in Puerto Rico (Corozal and Isabela) under black leaf streak disease pressure during a 3-year production cycle (2010-13). Values are means of six replications.

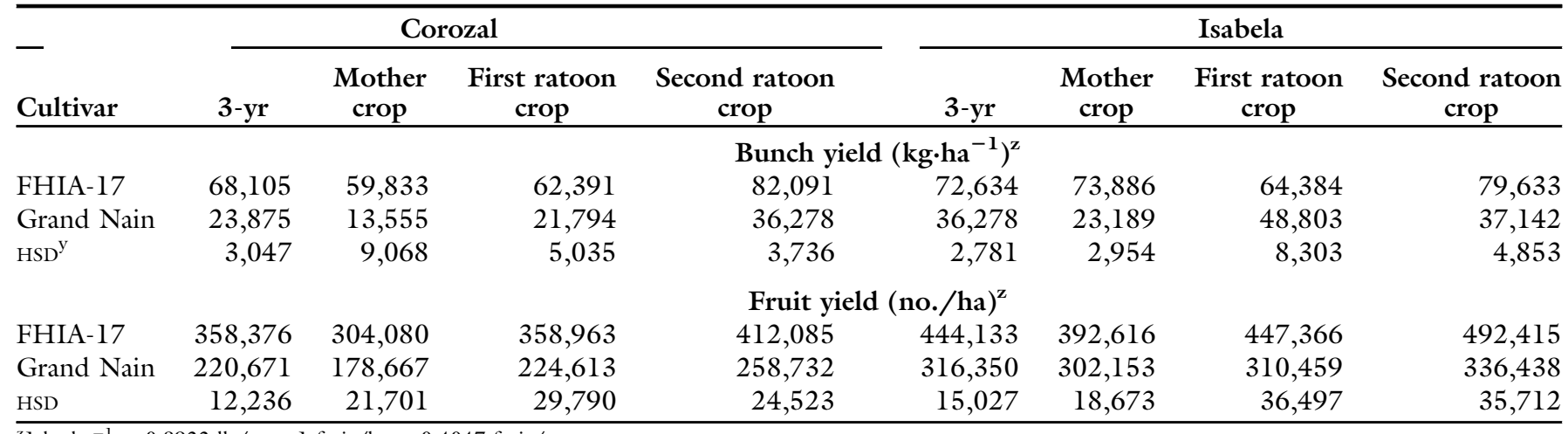

${ }^{\mathrm{z}} \mathrm{l} \mathrm{kg} \cdot \mathrm{ha}^{-1}=0.8922 \mathrm{lb} /$ acre, $\mathrm{l}$ fruit/ha $=0.4047$ fruit/acre.

${ }^{\mathrm{y}}$ Tukey's honestly significant difference test at $P=0.05$. 
Table 6. Black leaf streak disease severity on 'FHIA-17' and 'Grand Nain' banana planted at two locations in Puerto Rico. Values are means of six replications and 3 years (2010-13).

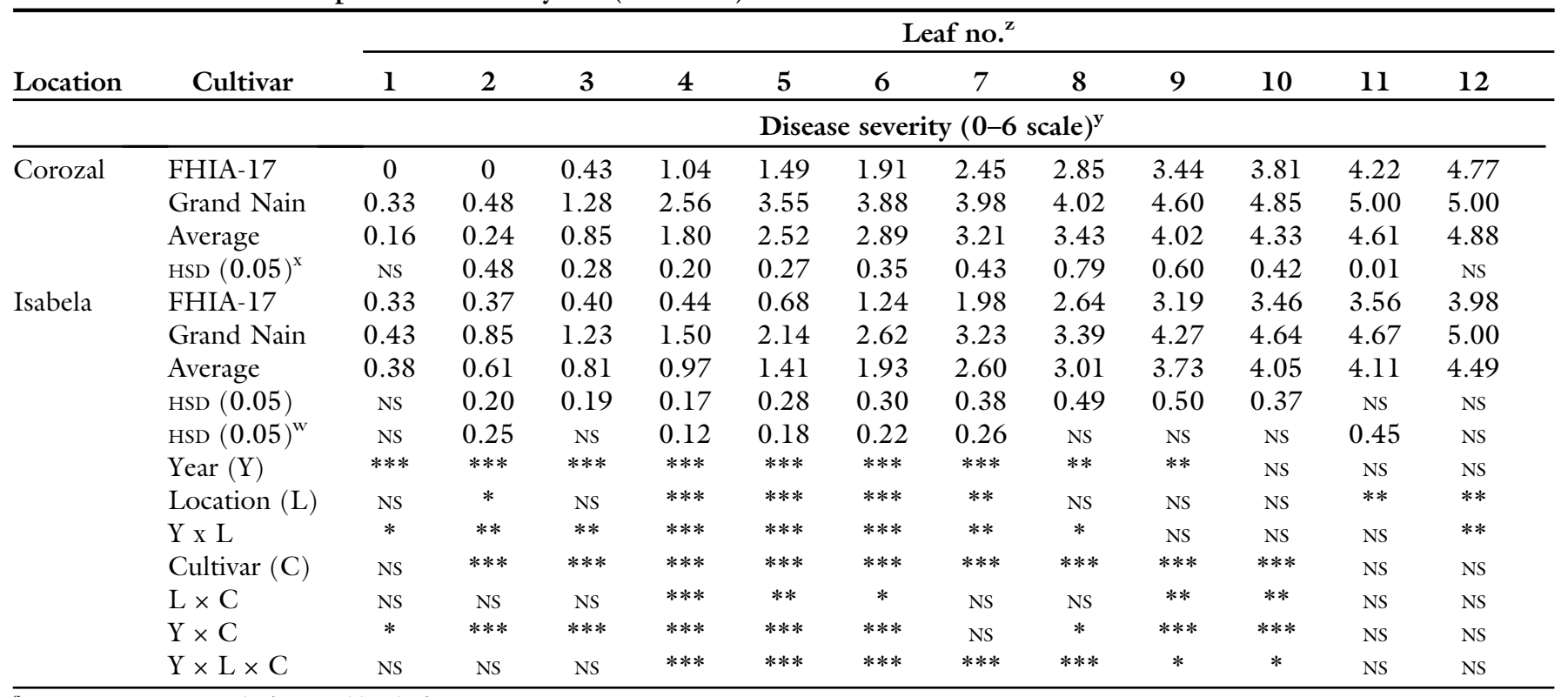

${ }^{\mathrm{z}} 1$ = youngest/top-most leaf, 12 = oldest leaf.

${ }^{\mathrm{y}}$ Disease severity based on a $0-6$ rating scale $(0=$ no symptoms; $1=1 \% ; 2=2 \%$ to $5 \% ; 3=6 \%$ to $15 \% ; 4=16 \%$ to $33 \% ; 5=34 \%$ to $50 \%$; and $6=>51 \%$ of the 1 eaf area affected) found in Orjeda (1998).

xukey's honestly significant difference test at $P=0.05$.

${ }^{\mathrm{w}}$ Compares means among locations.

Ns, $*, * *, * * *$ Nonsignificant or significant at $P \leq 0.05,0.01$, or 0.001 , respectively.

significantly greater diameter at both locations (Table 3). Average mean fruit weight was significantly higher at Corozal than at Isabela (Table 3). This could have been the result of fewer fruit per bunch competing for assimilates. At both locations, the mean fruit weight was significantly higher in 'FHIA-17' than in 'Grand Nain' (Table 3).

It is noteworthy that the harvest cycle of 'FHIA-17' was significantly longer than for 'Grand Nain'. It took 315 and $204 \mathrm{~d}$ more in Corozal and Isabela, respectively, to harvest three cycles (mother crop and two ratoon crops) of 'FHIA-17' than for 'Grand Nain' (Table 4). By the time the experiment was completed by harvesting the second ratoon crop (year 3 ) of 'FHIA-17' in Corozal, 'Grand Nain' plants had completed two additional cycles (third and fourth ratoons) that yielded 36,876 and $37,308 \mathrm{~kg} \cdot \mathrm{ha}^{-1}$, respectively (data not shown). A third ratoon cycle for 'FHIA-17' was still not completed at Corozal. However, in Isabela, a third ratoon of 'FHIA17' and 'Grand Nain' developed and yielded 73,088 and 43,919 $\mathrm{kg} \cdot \mathrm{ha}^{-1}$, respectively (data not shown). No fourth ratoon crop was completed for either cultivar in Isabela.

It is generally accepted that eight functional leaves at flowering time are sufficient for adequate bunch growth and development (Robinson et al., 1992; Vargas et al., 2009). Beyond the flowering stage, no new leaves are produced to contribute assimilates for fruit-filling. If the incidence of BLSD is high at flowering time or earlier, fruitfilling is compromised and bunch yield is reduced as a result of reduced leaf photosynthetic area. At both locations, the number of functional leaves at flowering was significantly higher in 'FHIA-17' than in 'Grand Nain' (Table 4). But more striking, at harvest time, 'FHIA-17' plants had significantly more functional leaves than 'Grant Nain'. This indicates that during the $\approx 100-\mathrm{d}$ period between flowering and harvest, 'FHIA-17' plants had more leaf photosynthetic area for adequate fruit-filling and possibly contributed to higher bunch yield in this cultivar at both locations. It also confirmed good BLSD resistance in 'FHIA-17'. In a recent study, Guillermet et al. (2018) compared two leaf management systems in banana planted at two locations over three production cycles. In one system ("Reference"), systemic and protective fungicides were applied every 3 to 5 weeks and BLSDdamaged leaf parts were removed every 7 to $15 \mathrm{~d}$. In the other system ("Prototype"), no fungicides were applied
4 months after planting, but sanitary leaf removal was made every 4 to $7 \mathrm{~d}$ to eliminate necrotic lesions caused by BLSD as soon as possible as they appeared. Their results showed that, except for cycle 3 (second ratoon) at one location, there were no significant differences in bunch yield between the reference and prototype systems. The authors concluded that relatively high yields in the prototype system with very small number of leaves present at harvest could be explained by manual defoliation occurring gradually rather than whole leaves cut at flowering as done in studies seeking to determine the effect of leaf pruning on bunch yield. The authors suggested that leaves present on flowering, for part of the filling-out phase, as well as remobilization of photosynthate from stems, bunch, and suckers, could have been responsible for adequate fruit-filling. In our study, no fungicides were applied at any time and leaves damaged by BLSD, or sections of these, were not cut from plants or removed from the experimental plots. In many banana-producing areas, the removal of BLSD-infected leaves every 4 to $7 \mathrm{~d}$ is not cost-effective due to significant increases in labor costs. This, as well as not having to apply fungicides, definitely is an advantage for using 'FHIA-17' as planting material. 
Table 7. Concentration of starch and soluble sugars at harvest time (mature green) and fully mature (ripened yellow) fruit of 'FHIA-17' and 'Grand Nain' banana. Values are means of three replications of fruit grown at Isabela, PR.

\begin{tabular}{lcccccccc}
\hline Cultivar & \multicolumn{3}{c}{ Starch glucose fructose sucrose } & \multicolumn{3}{c}{ Starch glucose fructose sucrose } \\
\hline & \multicolumn{3}{c}{ Harvest time $\left(\mathbf{m g} \cdot \mathbf{g}^{-\mathbf{1}}\right)^{\mathbf{z}}$} & \multicolumn{3}{c}{ Fully } & mature fruit $\left(\mathbf{m g} \cdot \mathbf{g}^{-\mathbf{1}}\right)$ \\
\hline FHIA-17 & 155 & ND & 2.26 & 7.56 & 96 & 30.2 & 49.0 & 224 \\
Grand Nain & 166 & ND & 1.46 & 3.47 & 95 & 24.6 & 47.9 & 232 \\
HSD $(0.05)^{y}$ & NS & NS & NS & NS & NS & NS & NS & NS \\
\hline
\end{tabular}

${ }^{\mathrm{z}} \mathrm{l} \mathrm{mg} \cdot \mathrm{g}^{-1}=1000 \mathrm{ppm}$.

'Tukey's honestly significant difference test at $P=0.05$

In industrialized nations, banana is mainly consumed ripe (sweet) but can also be consumed in many parts of the world as a staple starchy vegetable by boiling green fruit. When harvested (green and unripe), the concentration of starch is high and as the fruit matures, starch is converted to sugars and the peel color changes from green to yellow. Little is known about the organoleptic characteristics of 'FHIA17' fruit. To be accepted by consumers, organoleptic traits of 'FHIA-17' should be similar to commercial cultivars such as Grand Nain, one of the principal cultivars used in the export market. In this study, no significant differences were found for starch and soluble sugars in green unripe or fully mature fruit among cultivars (Table 7 ).

\section{Conclusions}

This long-term study demonstrated that 'FHIA-17' has resistance against BLSD, is a good producer, and may represent a viable alternative to current disease-susceptible cultivars. At the current (2021) farm gate price of $\$ 21.00$ per 40 -lb box of ripe banana fruit, the average fruit yield of 'FHIA17' (Table 3 ) would have amounted to gross profits of $\$ 78,826 /$ ha and $\$ 84,068 /$ ha at Corozal and Isabela, respectively, without the need to incur in fungicide application costs. However, its use should be considered after determining its cost-saving effects of not using fungicides (labor and product) vs. a longer harvest cycle than 'Grand Nain' to produce a fruit bunch. Studies conducted at Isabela and Corozal with 'Grand Nain' sprayed against yellow sigatoka, showed plants yielding as high as $70,700 \mathrm{~kg} \cdot \mathrm{ha}^{-1}$ $(\$ 81,830 / \mathrm{ha})$ and $47,900 \mathrm{~kg} \cdot \mathrm{ha}^{-1}$ $(\$ 55,44 \mathrm{l} / \mathrm{ha})$, respectively, at each location. At the time these studies were conducted, BLSD was not present in Puerto Rico (Goenaga and Irizarry, 1998, 2000) but spraying against yellow sigatoka control is not too different from for BLSD.

\section{Literature cited}

Alamo, C., E. Evans, A. Brugeras, and S. Nalampang. 2007. Economic impact and trade implications of the introduction of black sigatoka (Mycosphaerella fijiensis) into Puerto Rico. J. Agr. Appl. Econ. 39:5-17, https://doi.org/10.22004/ag. econ. 43218 .

Amacher, M.C. 2007. Nickel, cadmium and lead, p. 739-768. In: D.L. Sparks (ed.). Methods of soil analysis. Part 3 . Chemical methods. Soil Sci. Soc. Amer., Amer. Soc. Agron. Madison, WI, https:// doi.org/10.2136/sssabookser5.3.

Arzanlou, M., E. Abeln, G. Kema, C. Waalwijk, J. Carlier, I. de Vries, M. Guzman, and W. Crous. 2007. Molecular diagnostics for the sigatoka disease complex of banana. Phytopathology 97:1112-1118, https:// doi.org/10.1094/PHYTO-97-9-1112.

Bioversity International. 2020a. The banana plant. In: Musapedia, the banana knowledge compendium. 26 Dec. 2020. <https:// www.promusa.org/Banana+plant $>$.

Bioversity International. 2020b. Banana producing-countries. In: Musapedia, the banana knowledge compendium. 26 Dec. 2020. <https://www.promusa.org/ Banana-producing+countries+portal $>$.

Bioversity International. 2020c. Diversity of banana cultivars. 26 Dec. 2020. <https:// www.promusa.org/Diversity+of+banana + cultivars+portal!page_ref_id $=15>$.

Churchill, A.C.L. 2011. Mycosphaerella fijiensis, the black leaf streak pathogen of banana: Progress towards understanding pathogen biology and detection, disease development, and the challenges of control. Mol. Plant Pathol. 12:307-328, https:// doi.org/10.1111/j.1364-3703.2010.00 672.x

Crane, J.H. and C.F. Balerdi. 2019. Banana growing in the Florida home landscape. Univ. Florida, Florida Coop. Ext. Serv., Inst. Food Agr. Sci. Publ. HS-10. 26 Dec.
2020. <https://edis.ifas.ufl.edu/pdffiles/ MG/MG04000.pdf >.

Eckhard, G., W.H. Horst, and E. Neumann. 2012. Adaptation of plants to adverse chemical soil conditions, p. 420424. In: P. Marschner (ed.). Marschner's mineral nutrition of higher plants. Elsevier, Oxford, UK, https://doi.org/10.1016/ B978-0-12-384905-2.00017-0.

Etebu, E. and W. Young-Harry. 2011. Control of black sigatoka disease: Challenges and prospects. Afr. J. Agr. Res. 6:508-514, https://doi.org/10.5897/ AJARI0.223.

Food and Agriculture Organization of the United Nations (FAO). 2020. FAOSTAT statistics database 2019. 27 Dec. 2020. $<$ http://www.fao.org/faostat/en/\#data/ QC $>$.

Fundación Hondureña de Investigaciones Agrícolas. 2021. Programa de banano y plátano. 1 Jan. 2021. <http://www.fhia. org.hn/htdocs/banano_y_platano.html>.

Goenaga, R., H. Irizarry, and E. González. 1993. Water requirement of plantains (Musa acuminata x Musa balbisiana $\mathrm{AAB}$ ) grown under semiarid conditions. Trop. Agr. 70:3-7.

Goenaga, R. and H. Irizarry. 1995. Yield performance of banana irrigated with fractions of Class A pan evaporation in a semiarid environment. Agron. J. 87:172-176, https://doi.org/10.2134/agronj1995.00 021962008700020006x.

Goenaga, R. and H. Irizarry. 1998. Yield of banana grown with supplemental drip-irrigation on an Ultisol. Exp. Agr. 34:439448, https://doi.org/10.1017/S001447 9798004062 .

Goenaga, R. and H. Irizarry. 2000. Yield and quality of banana irrigated with fractions of Class A pan evaporation on an Oxisol. Agron. J. 92:1008-1012, https://doi. org/10.2134/agronj2000.9251008x.

Goenaga, R. and H. Irizarry. 2006. Yield performance of two French-type plantain clones subjected to bunch pruning. J. Agr. Univ. P. R. 90:173-182, https:// doi.org/10.46429/jaupr.v90i3-4.1005.

Goenaga, R., B. Irish, and A. Marrero. 2019. Yield and fruit quality traits of two plantain cultivars grown at two locations in Puerto Rico under black leaf streak disease pressure. HortTechnology 29:958-966, https://doi.org/10.21273/HORTTECH 04425-19.

Guillermet, C., R. Le Guen, M. Dorel, T. Lescot, and L. de Lapeyre de Bellaire. 2018. Experimental approaches for agroecological management of black leaf streak in dry and humid tropical conditions. 
Acta Hort. 1196:113-120, https://doi. org/10.17660/ActaHortic.2018.1196.13.

Irish, B.M., R. Goenaga, and R. Ploetz. 2006. Mycosphaerella fijiensis, causal agent of black sigatoka of Musa spp. found in Puerto Rico and identified by polymerase chain reaction. Plant Dis. 90:684, https:// doi.org/10.1094/PD-90-0684A.

Irish, B.M., R. Goenaga, C. Rios, J. Chavarria-Carvajal, and R. Ploetz. 2013. Evaluation of banana hybrids for tolerance to black leaf streak (Mycosphaerella fijiensis Morelet) in Puerto Rico. Crop Prot. 54:229-238, https://doi.org/10.1016/j. cropro.2013.09.003.

Irizarry, H., E. Rivera, and J. Rodriguez. 1988. Nutrient uptake and dry matter composition in the plant crop and first ratoon of the Grand Naine banana grown on an Ultisol. J. Agr. Univ. P. R. 72: 337-351, https://doi.org/10.46429/jaupr. v72i3.6862.

Irizarry, H., E. Rivera, I. Beauchamp de Caloni, and R. Guadalupe. 1989. Performance of elite banana (Musa acuminata, AAA) cultivars in four locations of Puerto Rico. J. Agr. Univ. P. R. 73:209-221, https://doi.org/10.46429/jaupr.v73i3. 6459.

Irizarry, H., E. Rivera, and J. Rodriguez. 1990. Response of bananas (Musa acuminata, AAA) to magnesium fertilization in an Ultisol. J. Agr. Univ. P. R. 74:419-426, https://doi.org/10.46429/jaupr.v74i4. 6680 .

Irizarry, H., R. Goenaga, and U. Chardon. 2000. Effectiveness of magnesium source and rate in the fertilization of banana grown on an Ultisol in Puerto Rico. J. Agr. Univ. P. R. 84:35-45, https://doi.org/10.46429/ jaupr.v84il-2.3899.

Irizarry, H., R. Goenaga, and $\mathrm{O}$. González. 2001. Characterization and grouping of plantain clones on the basis of their genomic constitution and morphological traits of economic importance. J. Agr. Univ. P. R. 85:105-126, https:// doi.org/10.46429/jaupr.v85i3-4.3065.

Johanson, A. and M.J. Jeger. 1993. Use of PCR for detection of Mycosphaerella fijiensis and M. musicola, the causal agents of sigatoka leaf spots in banana and plantain. Mycol. Res. 97:670-674, https://doi. org/10.1016/S0953-7562(09)80145-7.

Maymon, M., N. Sela, U. Shpatz, N. Galpaz, and S. Freeman. 2020. The origin and current situation of Fusarium oxysporum $\mathrm{f}$. sp. cubense tropical race 4 in Israel and the Middle East. Sci. Rep. 10:1590-1600, https://doi.org/10.1038/s41598-020-58 378-9.
Mulvaney, R.L. 2007. Nitrogen: Inorganic forms, p. 1123-1184. In: D.L. Sparks (ed.). Methods of soil analysis. Part 3. Chemical methods. Soil Sci. Soc. Amer., Amer. Soc. Agron., Madison, WI, https:// doi.org/10.2136/sssabookser5.3.

Nelson, D.W. and L.E. Sommers. 2007. Total carbon, organic carbon and organic matter, p. 961-1010. In: D.L. Sparks (ed.). Methods of soil analysis. Part 3. Chemical methods. Soil Sci. Soc. Amer., Amer. Soc. Agron., Madison, WI, https://doi.org/ 10.2136/sssabookser5.3.

Orjeda, G. 1998. Evaluation of Musa germplasm for resistance to sigatoka diseases and fusarium wilt. INIBAP Technical Guidelines 3. Int. Plant Genet. Resour. Inst., Rome, Italy; Int. Network Improv. Banana Plantain, Montpellier, France; ACP-EU Tech. Centre Agr. Rural Coop., Wageningen, The Netherlands.

Ortiz, R., D. Vuylsteke, H. Crouch, and J. Crouch. 1998. TM3x: Triploid black sigatoka-resistant Musa hybrid germplam. HortScience 33:362-365, https://doi. org/10.21273/HORTSCI.33.2.362.

Perrier, X., E. De Langhe, M. Donohue, C. Lentfer, L. Vrydaghs, F. Bakry, F. Carreel, I. Hippolyte, J.P. Horry, C. Jenny, V. Lebot, A.M. Risterucci, K. Tomekpe, H. Doutrelepont, T. Ball, J. Manwaring, P. de Maret, and T. Denham. 2011. Multidisciplinary perspectives on banana (Musa spp.) domestication. Proc. Natl. Acad. Sci. USA 108:11311-11318, https://doi.org/ 10.1073/pnas.1102001108.

Ploetz, R.C. and X. Mourichon. 1999. First report of black sigatoka in Florida. Plant Dis. 83:300, https://doi.org/ 10.1094/PDIS.1999.83.3.300C.

Rhodes, P.L. 1964. A new banana disease in Fiji. Commonwealth Phytopathol. News 10:38-41.

Robinson, J.C., T. Anderson, and K. Eckstein. 1992. The influence of functional leaf removal at flower emergence on components of yield and photosynthetic compensation in banana. J. Hort. Sci. 67:403-410, https://doi.org/10.1080/ 00221589.1992 .11516265 .

Robinson, J.C. and V. Galán-Saúco. 2010. Bananas and plantains. CABI Int., Wallingford, UK, https://doi.org/10.1079/978 1845936587.0000 .

Rowe, P. and F. Rosales. 1993. Diploid breeding at FHIA and the development of Goldfinger(FHIA-01). Infomusa 2:9-11.

Simmonds, N.W. and K. Shepherd. 1955. The taxonomy and origins of the cultivated bananas. Bot. J. Linn. Soc. Lond.
Botany 55:302-312, https://doi.org/ 10.1111/j.1095-8339.1955.tb00015.x.

Subbaraya, U., M.S. Saraswathi, and M. Pillay. 2011. Evolution and genetic relationships in banana and plantains, p. 21-39. In: M. Pillay and A. Tenkouano (eds.). Banana breeding. CRC Press, Boca Raton, FL, https://doi.org/10.1201/b10514.

Sumner, M.E. and W.P. Miller. 2007. Cation exchange capacity and exchange coefficients, p. 1201-1230. In: D.L. Sparks (ed.). Methods of soil analysis. Part 3. Chemical methods. Soil Sci. Soc. Amer., Amer. Soc. Agron. Madison, WI, https:// doi.org/10.2136/sssabookser5.3.

Swennen, R. and D. Vuylsteke. 1993. Breeding black sigatoka resistant plantains with a wild banana. Trop. Agr. 70:74-78.

University of Puerto Rico, Agricultural Experiment Station. 1995. Technological package for the production of plantains and bananas. Univ. Puerto Rico, Rio Piedras, Publ. 97.

U.S. Department of Agriculture (USDA). 1999. Soil taxonomy, a basic system of soil classification for making and interpreting soil surveys. Agr. Handbook No. 436. 9 Jan. 2019. <https://www.nrcs.usda.gov/ Internet/FSE_DOCUMENTS/nrcs142p2 051232.pdf $>$.

U.S. Department of Agriculture (USDA). 2004. Bananas: Market inspection instructions. 27 Dec. 2020. < https://www.ams. usda.gov/grades-standards/bananasinspection-instructions $>$.

U.S. Department of Agriculture (USDA). 2017. 2017 Census of agriculture. 27 Dec. 2020. <https://www.nass.usda.gov/ Publications/AgCensus/2017/Full_ Report/Volume_1,_Chapter_1_State_ Level/>.

Vargas, A., M. Araya, M. Guzman, and G. Murillo. 2009. Effect of leaf pruning at flower emergence of banana plants (Musa AAA) on fruit yield and black sigatoka (Mycosphaerella fijiensis) disease. Intl. J. Pest Mgt. 55:19-25, https://doi.org/ 10.1080/09670870802450219.

Vuylsteke, D.R. 1989. Shoot-tip culture for the propagation, conservation and exchange of Musa germplasm. Intl. Board Plant Genet. Resour., Rome, Italy.

Yonow, T., J. Ramirez-Villegas, C. Abadie, R.E. Darnell, N. Ota, and D.J. Kriticos. 2019. Black sigatoka in bananas: Ecoclimatic suitability and disease pressure assessments. PLoS One 14(8):e0220601, https://doi.org/10.1371/journal.pone. 0220601 . 